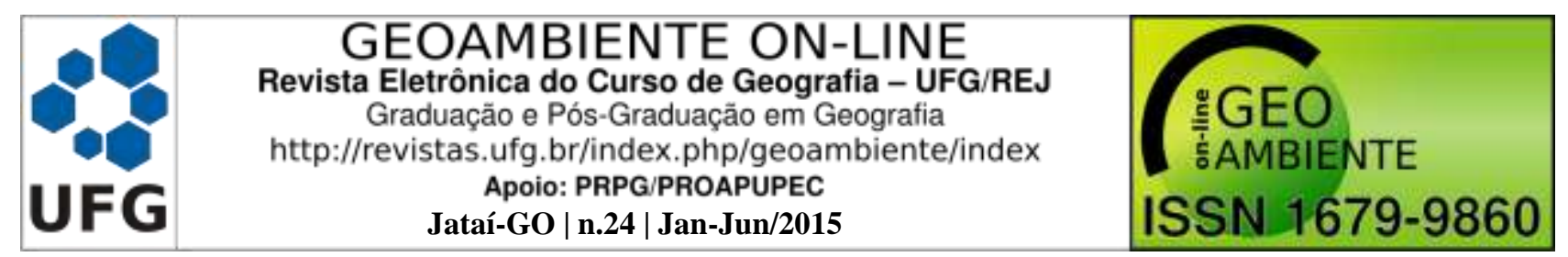

\title{
ANTROPOGEOMORFOLOGIA - O HOMEM COMO AGENTE GEOMORFOLÓGICO: BASE TEÓRICA E ANÁLISE ACERCA DA EXTRAÇÃO DO AMIANTO CRISOTILA EM MINAÇU (GO)
}

\author{
José Carlos de Souza ${ }^{1}$,Uhênia Caetano Pereira ${ }^{2}$
}

(1 - Universidade Estadual de Goiás, Professor do Curso de Geografia, Doutorando em Ciências Ambientais - UNESP, zecarlossouza1974@hotmail.com; 2- Universidade Estadual de Goiás, Professora do Curso de Geografia, uhenea@ hotmail.com)

\section{“... do arado aos explosivos, o homem vem a pelo menos 8000 anos modificando as formas da Terra” (Brown, 1971).}

Resumo: Este trabalho apresenta uma analise espacial e temporal do processo de extração do amianto crisotila no município de Minaçu, no Estado de Goiás e sua relação com a elaboração de formas antropogênicas. As analises foram feitas a partir da correlação entre os aspectos morfológicos e morfométricos da área e os dados históricos da produção do mineral. $\mathrm{O}$ processo de extração iniciou-se em 1967 de forma rudimentar, mas com o aumento da demanda mundial pelo minério e a modernização tecnológica do processo, as alterações na paisagem se tornaram crescentes e cumulativas. Neste período foram removidos centenas de milhões de toneladas de rocha e solo, elaborando cavas e bancas de rejeito que surpreendem por suas dimensões. Vinculada a estas análises, temos uma breve discussão teórica acerca da Geomorfologia Antrópica como especialidade da Geomorfologia, aplicada às alterações no meio físico provocadas pelas ações humanas diretas e indiretas.

Palavras-chave: Geomorfologia, Antropogeomorfologia, Mineração de amianto.

\section{ANTHROPOGEOMORPHOLOGY - MAN AS A GEOMORPHOLOGIC AGENT: THEORETICAL BASIS AND ANALYSIS OF CHRYSOTILE EXTRACTION IN MINAÇU, STATE OF GOIÁS, BRAZIL.}

Abstract: The present work show a spatial and temporal analysis from the chrysotile asbestos and the relation with a development of anthropogenic forms in the city of Minaçu, State of

Artigo recebido para publicação em 21 de Fevereiro de 2015 


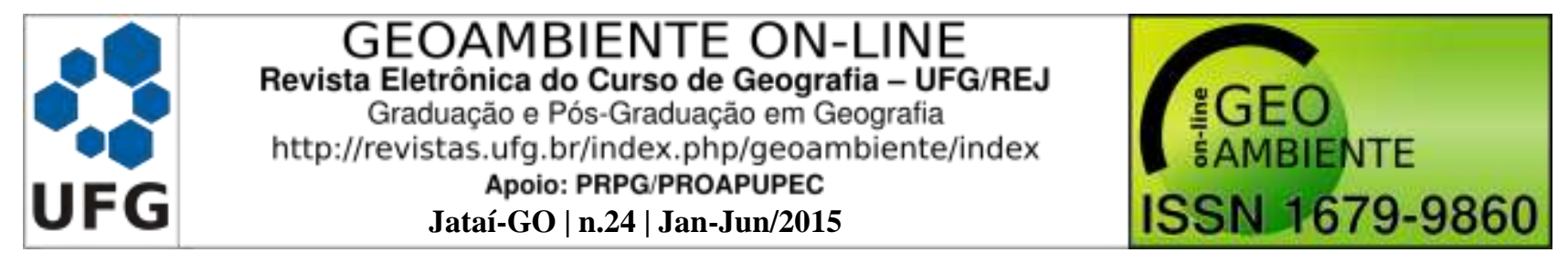

Goias. The analyses were done from the correlation between the morphological and morphometric aspects from area and historical data of the mineral production. The extraction process began in 1967 in a rudimentary way, although with the increase of the global demand for the ore and the technological modernization process, the changes in the landscape became increasing and cumulative. During this period were removed hundreds of millions of tonnes of rock and soil, drawing up armholes and embankment of waste that surprised by its dimensions. Linked to these analyzes, we have a theoretical discussion about the Anthropic Geomorphology as specialty of Geomorphology, applied to changes in the physical environment caused by direct and indirect human actions.

Keywords: Geomorphology, Anthropogeomorphology, Amianthus mining.

\section{Antropogeomorfología - El Hombre como Agente Geomorfológico: Base Teórica y Análisis sobre la Extracción del Amianto Blanco en Minaçu (GO).}

Resumen: La obra presenta un análisis espacial y temporal del proceso de extracción del amianto blanco y su relación con el desarrollo de formas antropogénicas en el municipio de Minaçu, en el estado de Goiás. Los análisis se realizaron a partir de la correlación entre los aspectos morfológicos y morfométricos del área y los datos históricos de producción del mineral. El proceso de extracción se inició en 1967 de forma rudimentaria, pero, con la creciente demanda mundial del mineral y la modernización tecnológica del proceso, los cambios en el paisaje se han tornado crecientes y acumulativos. En este periodo se retiraron cientos de millones de toneladas de roca y tierra, produciéndose pozos y puestos de residuos que sorprenden por sus dimensiones. Vinculada a estos análisis, hay una discusión teórica sobre la Geomorfología Antrópica como especialidad de la Geomorfología, aplica a los cambios en el ambiente físico causados por acciones humanas directas e indirectas.

Palabras claves: Geomorfología, Antropogeomorfología, Minería de amianto.

\section{Introdução}

A Geomorfologia é uma ciência que tem evoluído tanto em seus métodos e técnicas de análise, quanto nos conceitos que os pesquisadores lhe atribuem. Felds (1957) a considera como uma ciência da ação e da eficácia das forças da natureza inanimada modelando a multiplicidade das formas da superfície da Terra; Brown (1971) a define como a ciência da forma da Terra, o estudo do modelado terrestre. No século XX, entre estudiosos brasileiros, se percebe uma definição mais detalhada para a ciência, como pode ser identificado nos trabalhos de Christofoletti (2001) e Casseti (2001), que consideram que essa ciência tem 


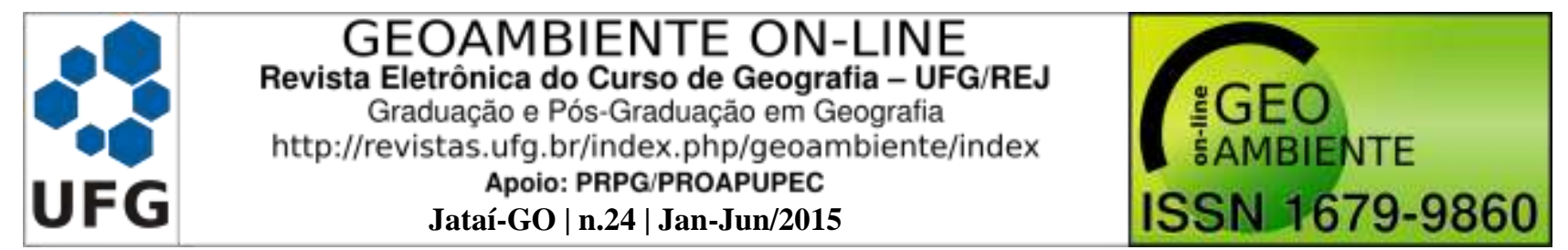

como finalidade, analisar as formas de relevo com sua dinâmica evolutiva pretérita e atual focalizando suas características morfológicas, materiais componentes, processos atuantes e fatores controlantes.

Os conceitos modernos de Geomorfologia evidenciam a natureza, a gênese, a composição dos materiais e como esses processos se desenvolvem na elaboração das formas de relevo (GUERRA e MARÇAL, 2006; FLORENZANO, 2008). Os estudos têm avançado e os temas da Geomorfologia têm se diversificado, principalmente no intuito de compreender as transformações do meio físico provocadas pelo homem.

Especialidades, como Geomorfologia Ambiental e Geomorfologia Urbana, têm sido amplamente exploradas na atualidade por pesquisadores da área. Esses estudos têm contribuído sobremaneira no diagnóstico, planejamento e gestão de áreas degradadas e/ou de risco em áreas urbanas e onde se desenvolvem atividades como agricultura, pastagem, mineração e outras.

As alterações provocadas pelo homem na superfície terrestre, planejadas ou não, têm se tornado objetos especiais de estudos da geomorfologia, considerando o homem como agente geomorfológico. Felds, na década de 1950, já se preocupava com as ações humanas sobre o meio físico, fazendo críticas quanto aos poucos trabalhos e pesquisas sobre o assunto desenvolvido na época, e cita como sua contribuição para o entendimento dessas intervenções a publicação em alemão intitulada "A atividade econômica do homem muda a face da terra" (FELDS, 1957).

Brown, em seu artigo intitulado "O homem modela a Terra", publicado pelo Boletim Geográfico Brasileiro em 1971, também fazia referência ao homem como um dos agentes exógenos modeladores do relevo. Neste mesmo artigo, apresenta o termo Antropogeomorfologia, que, segundo ele, foi proposto por Golomb e Eder em 1964 (BROWN, 1971).

A Antropogeomorfologia surge como uma especialidade da Geomorfologia que tem como objetivo analisar os impactos nos solos e as alterações no relevo provocadas pela ação humana (GOUDIE, 1993 apud SANTOS FILHO, 2011). Expressões como Geomorfologia Antropogenética (FELDS, 1957), Geomorfologia Antrópica (Marques, 2001), Morfogênese Antrópica (JORGE, 2011), Morfologia Antropogênica (RODRIGUES, 2005), dentre outras, também são utilizadas para fazer referência à ação humana sobre as formas de relevo.

O avanço tecnológico e o aprimoramento das técnicas de engenharia têm contribuído sobremaneira para a transformação da natureza e a criação de paisagens artificiais para 


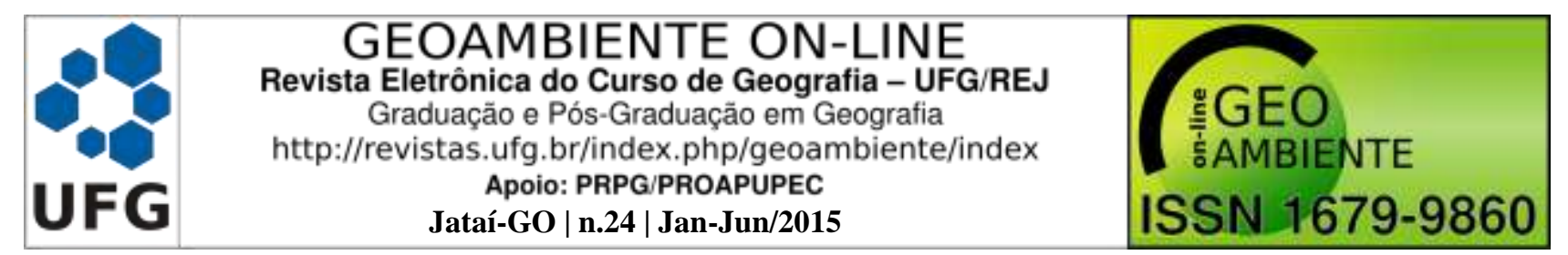

atender aos interesses da sociedade moderna. Segundo Santos (1996) quanto mais complexos a vida social, tanto mais nos distanciamos de um mundo natural e nos endereçamos a um mundo artificial. Esses elementos artificiais são considerados por este autor como próteses ou acréscimos à própria natureza, assim como estradas, edifícios, pontes, portos, depósitos, entre outros.

Frente a estas abordagens que legitimam o homem como agente geomorfológico é que se propõe, neste trabalho, apresentar os resultados de uma análise que tem por objetivo avaliar a ação do homem na modelação do relevo, no processo de extração do amianto crisotila, no município de Minaçu, no norte do Estado de Goiás (Mina de Cana Brava), baseado nos pressupostos teóricos da Geomorfologia e de sua especialidade - a Antropogeomofologia.

A mina Cana Brava situa-se no município de Minaçu, norte do Estado de Goiás, a 510 km da cidade de Goiânia. Está localizada na margem esquerda do Rio Tocantins, ocupando uma área total de $45 \mathrm{~km}^{2}$ (Figura 1). A área de concessão estadual abrange 4.500 ha, sendo que deste total, aproximadamente, $20 \%$ são destinados à mineração, $10 \%$ ao reflorestamento e $70 \%$ representa a reserva natural de vegetação nativa.

Figura 1: Localização da mina de extração de amianto crisotila, Minaçu (GO).

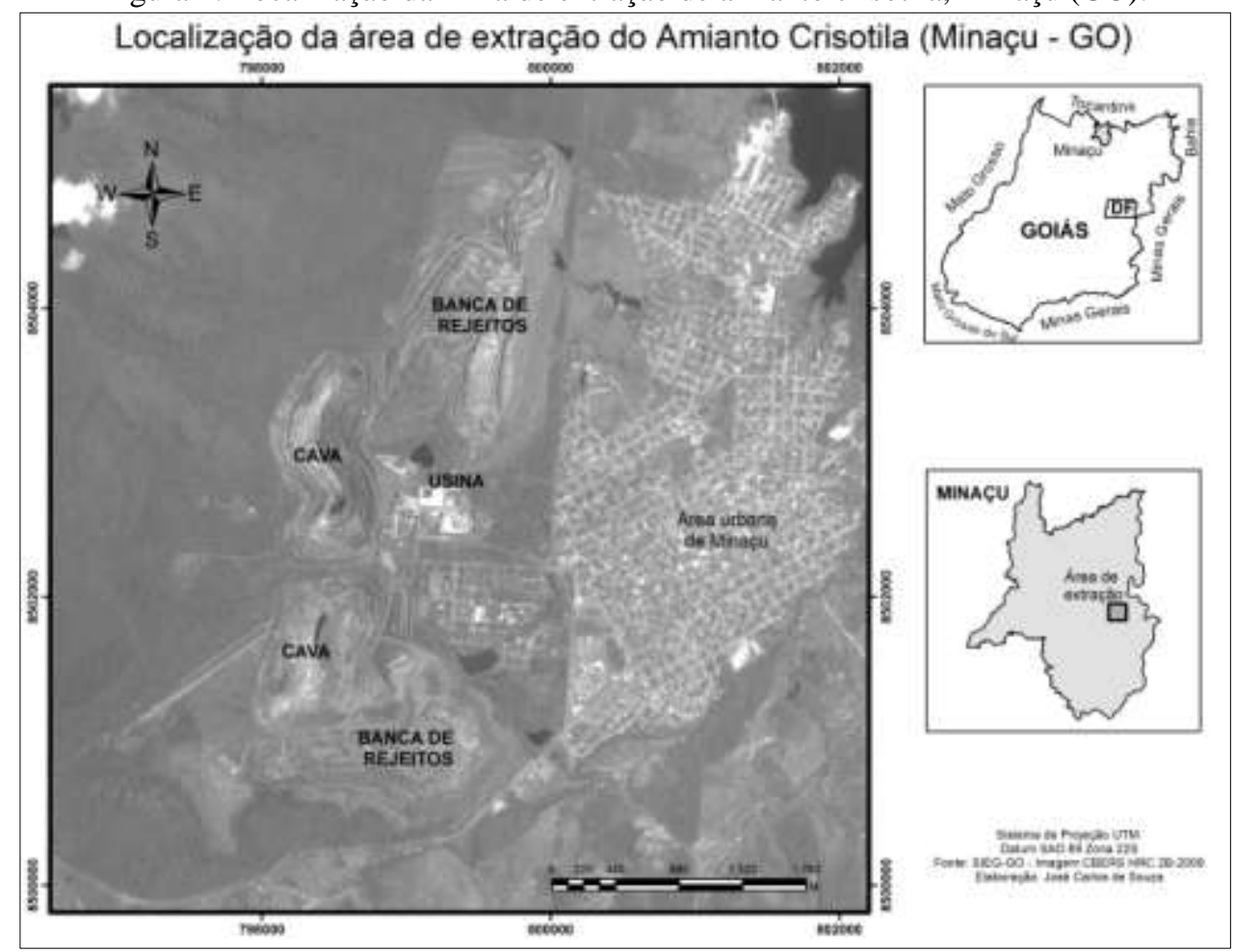

Fonte: Imagem CBERS_2B_HRC-INPE/2009.

O processo de extração do amianto crisotila teve seu início por volta 1967. Desse período até os dias atuais a empresa SAMA Minerações Associadas vem extraindo o minério 


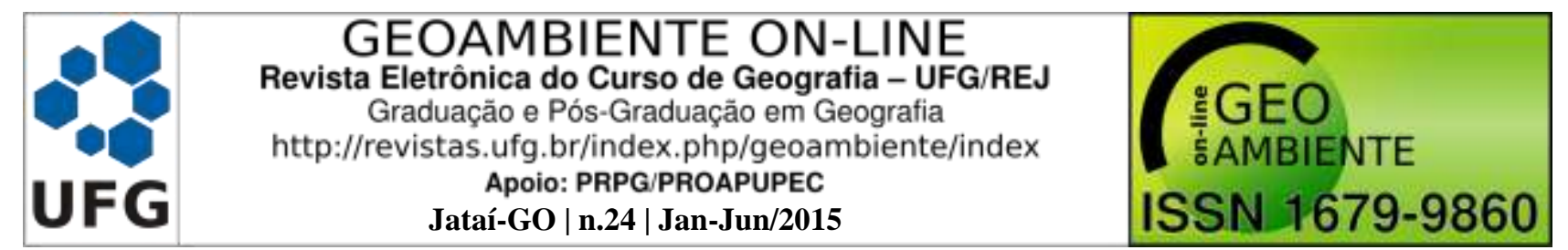

e transformando a paisagem geomorfológica da área a partir do processo de extração, beneficiamento do minério e descarte do rejeito, elaborando formas negativas, como as cavas, e positivas, como as bancas de rejeito. Para realizarmos esta análise faremos uma incursão teórica pelo relevo como objeto de estudo da Geomorfologia e da Antropogeomorfologia como especialidade.

\section{Material e Métodos}

O trabalho é resultado de uma revisão bibliográfica acerca do homem como agente geomorfológico e do conceito de Antropogeomorfologia como especialidade da Geomorfologia. Para isso foi realizado uma incursão em publicações nas áreas de Geografia, Geomorfologia e Geologia para a construção de um embasamento teórico.

Procedeu-se uma descrição do meio físico da área da mineração, para levantamento dos aspectos morfológicos originais (morfologia original), e a descrição dos aspectos morfométricos atuais (morfologia antropogênica). Estas descrições foram realizadas com base em Goiás (2006), Moreira et al. (2008) e dados disponibilizados no sítio do Sistema de Informações Geográficas de Goiás - SIEG ${ }^{1}$. Os dados quantitativos e do processo de produção do amianto crisotila na mina de Cana Brava foram obtidos junto ao Departamento Nacional de Produção Mineral - DNPM e no site da empresa Sama Minerações Associadas².

Para a elaboração dos mapas de localização e delimitação da área de estudo foram utilizadas como base imagens do satélite CBERS 2B HRC (High Resolution Camera) de 15 de março de 2009, disponível no site do Instituto de Pesquisas Espaciais - INPE (www.inpe.br). Para a confecção do mapa de relevo sombreado, com curvas de nível, bem como os perfis topográficos, foi utilizado o Modelo Digital de Elevação (MDE), elaborado a partir de dados SRTM (Shuttle Radar Topography Mission) por TOPODATA (Banco de Dados Geomorfométricos do Brasil), disponibilizado também pelo INPE ${ }^{3}$. Os mapas foram elaborados em ambiente ArcGis 9.3.

\section{Base teórica - a antropogeomorfologia como especialidade}

A Geomorfologia inicia seu processo de sistematização no final do século XIX e toma corpo como ciência autônoma no início do século XX. Como todas as outras áreas do conhecimento, passou a experimentar uma expansão e aprofundamento em seus estudos, que

\footnotetext{
${ }^{1}$ http://www.sieg.go.gov.br/

${ }^{2}$ www.sama.com.br

${ }^{3}$ http://www.dsr.inpe.br/topodata/)
} 


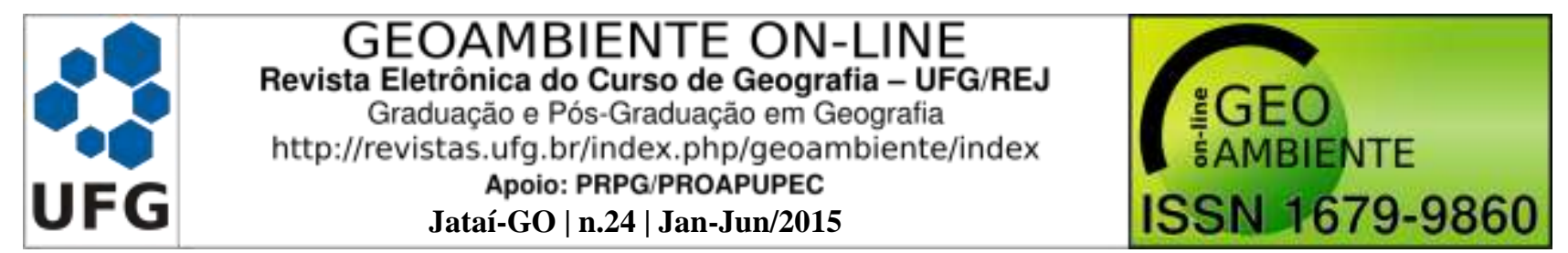

influenciaram o surgimento das especialidades. Marques (2001) apresenta algumas delas que considera como subdivisões desta ciência: Geomorfologia Estrutural, Geomorfologia Climática, Geomorfologia Costeira, Geomorfologia Continental, Geomorfologia Regional, Geomorfologia Aplicada, Geomorfologia Dinâmica e Geomorfologia do Quaternário.

A Geomorfologia Aplicada surge em 1970 com intuito de diagnosticar e apresentar soluções para os problemas ambientais resultantes das transformações do relevo e dos processos superficiais causados pelo homem (PENTEADO, 1983). A partir dos anos 1990 os termos Geomorfologia Ambiental e Geomorfologia Urbana, passam a ser amplamente utilizados pelos pesquisadores das áreas de geociências.

Segundo Guerra e Marçal (2006), a geomorfologia vem sendo utilizada cada vez mais para o planejamento, na medida em que procura contribuir para o entendimento das transformações do meio físico causadas pela ocupação humana. Estes autores são uns dos divulgadores de uma das especialidades da geomorfologia, a "geomorfologia ambiental". A geomorfologia ambiental tem como objetivo fazer uma análise ambiental que leve em consideração a exploração dos recursos naturais, com vistas a identificar as mudanças físicas nos ecossistemas terrestres e aquáticos, a partir da intervenção humana, ou seja, diagnosticar e prognosticar a degradação ambiental causada pelo homem.

A geomorfologia urbana é uma especialidade da geomorfologia que vem para explicar as transformações provocadas pelo homem no meio físico, em sítios urbanos. Jorge (2011) apresenta como morfogênese antrópica em áreas urbanas a erosão e a produção de sedimentos e lista como objeto de estudo da geomorfologia urbana o assoreamento, o corte de taludes, os aterros e os movimentos de massa induzidos, a mineração em área urbana e periurbana e as inundações e alagamentos.

Tanto na Geomorfologia Ambiental, quanto na Urbana, o principal enfoque é analisar as transformações provocadas pelo homem na superfície terrestre, considerando-o como um agente geomorfológico que tem um alto potencial de desconstruir e construir formas de relevo. Neste sentido Felds (1957, p.357) faz a seguinte observação: "chego à conclusão de que se pode sem objeção válida colocar a ação geomorfológica do homem sob o mesmo plano que as mudanças operadas pela natureza".

Para Felds (1957), o homem intervém no meio físico na qualidade de agente geomorfológico com o emprego de seus utensílios de trabalho (tecnologias). A participação do homem na modificação das formas da terra cresce na medida em que a técnica progride. Deve-se considerar a participação do homem nos fatos e na evolução geomorfológica, pois o 


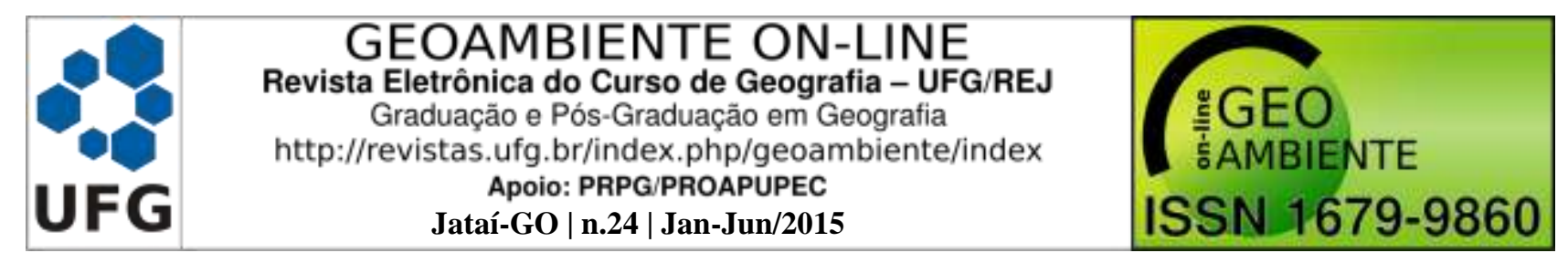

homem exerce numerosos efeitos diretos ao executar grandes deslocamentos de massa, como, por exemplo, nas construções de habitações, exploração mineral, agricultura, infraestrutura de transporte e outros.

Brown em seu artigo "O homem modela a Terra", publicado em 1971, insere o homem nos processos exógenos de modelação do relevo ao lado dos fenômenos naturais relacionados aos intemperismos químico e físico. Este autor faz um resgate acerca dos principais trabalhos publicados até aquele momento sobre o tema e cita a contribuição de Sherlock, com o trabalho O homem como agente geológico publicado em 1922; Jacks e Whyte, que realizaram um estudo fazendo referência ao homem como causador da erosão dos solos em 1939; as contribuições europeias com o francês Jean Tricart na década de 1950, e a tentativa de Golomb e Eder, na Califórnia em 1964, de tornar a Antropogeomorfologia uma ciência.

Somada a estas contribuições, podemos também citar, o trabalho intitulado Man, a geomorphological agent: an introduction to anthropic geomorphology de autoria de Nir (1982 apud RODRIGUES, 2005), onde o termo Antropogeomorfologia também é utilizado, fazendo referência ao homem como agente Geomorfológico.

Vários autores dão ênfase às transformações na superfície da Terra provocadas pelo homem. Para Marques (2001), o homem cada vez mais diversifica e intensifica sua atuação, criando condições de interferir e, até mesmo, controlar os processos, criar e destruir formas de relevo. Rodrigues (2005) faz referência a essa capacidade de transformação do meio físico, provocada pelo homem, chamando atenção para a diferença que há entre a Antropogeomorfologia e outras abordagens:

A diferença fundamental para outras abordagens é a consideração da própria interferência antrópica como ação geomorfológica, ação essa que pode: modificar propriedades e localização dos materiais superficiais; interferir em vetores, taxas e balanços dos processos e gerar, de forma direta e indireta, outra morfologia (RODRIGUES, 2005 p. 101).

Para Casseti (2001), é no contexto da fisiologia da paisagem que o homem se insere como agente geomórfico, ou seja, agente modelador do relevo. Quanto à fisiologia da paisagem, tem ela como objetivo compreender a ação dos processos morfodinâmicos atuais, momento em que o homem se insere como sujeito modificador. Segundo Peloggia (1998), o homem passa a provocar essas alterações a partir da Revolução Neolítica, em torno de nove e dez mil anos atrás (ou antes do presente), com as práticas agrícolas e pastoris.

Goudie (1993 apud GIRÃO e CORRÊA, 2004) classifica os processos antropogeomorfológicos em diretos, quando se tratam de intervenções humanas propositais, 


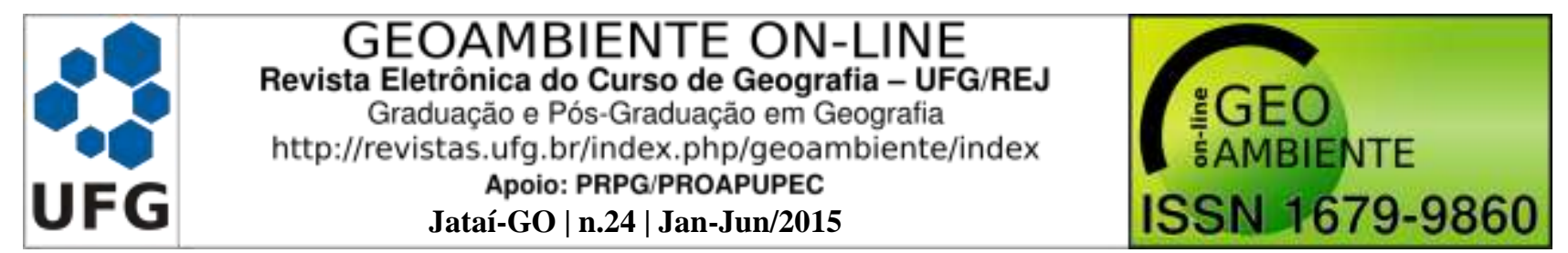

como aragem da terra, construções diversas, escavações, corte de encostas, mineração, modificação de canais fluviais, entre outros, e indiretos, quando as consequências de alguma intervenção não são propositais, como processos erosivos acelerados, movimentos de massa, subsidência, assoreamento, dentre outros.

A evolução tecnológica e a crescente necessidade humana de produzir recursos e de adaptar a natureza às suas necessidades têm provocado alterações significativas no meio físico e essas alterações nos ambientes rocha-relevo-solo, sejam propositais ou não, são objetos de estudo da Antropogeomorfologia e a legitimação dessa especialidade se deve à evolução teórico-metodológico da Geomorfologia enquanto ciência, e à necessidade crescente de se conhecer o sistema relevo para planejar sua apropriação e entender seu comportamento pósocupação.

\section{Resultados e discussões - O processo de extração de amianto e a elaboração das formas antropogênicas}

A mineração é uma das atividades humanas que mais provocam alterações no relevo, especialmente aquelas que necessitam remover grandes quantidades de rocha e solo para extrair o minério. Uma das modalidades desse processo, a extração a céu aberto, que se processa basicamente na escavação, beneficiamento e deposição de rejeitos, imprime significativas mudanças na paisagem morfológica, como feições negativas, representadas pelas cavas, e feições positivas, representadas pelas bancas de rejeito.

O processo de extração do amianto crisotila em Minaçu é um exemplo de mineração a céu aberto, que, desde meados da década de 1960, vem elaborando formas antropogênicas, em uma demonstração explícita do homem como agente geomorfológico em um contexto de antropogeomofologia direta, com ações planejadas, onde as alterações são propositais. A mina de Cana Brava detém 100\% das reservas nacionais de amianto crisotila, cuja exploração é feita pela única mineradora de amianto no país, a SAMA S.A. Minerações Associadas.

$\mathrm{O}$ amianto crisotila é um silicato hidratado de magnésio $\left(\mathrm{Mg}_{3} \mathrm{Si}_{2} \mathrm{O}_{5}(\mathrm{OH}) 4\right)$, fibroso e ocorre em veios incrustados em serpentinitos fraturados ou falhados na porção sul do Complexo Máfico-Ultramáfico Cana Brava (MOREIRA et al. 2008). Esse complexo se configura morfologicamente como morros e colinas com forte controle estrutural, resultado de processos de dobramento (GOIÁS, 2006). A fibra de amianto é utilizada como fibrocimento na produção de telhas e caixas d'água, produtos de fricção, como pastilhas, lonas de freios e 


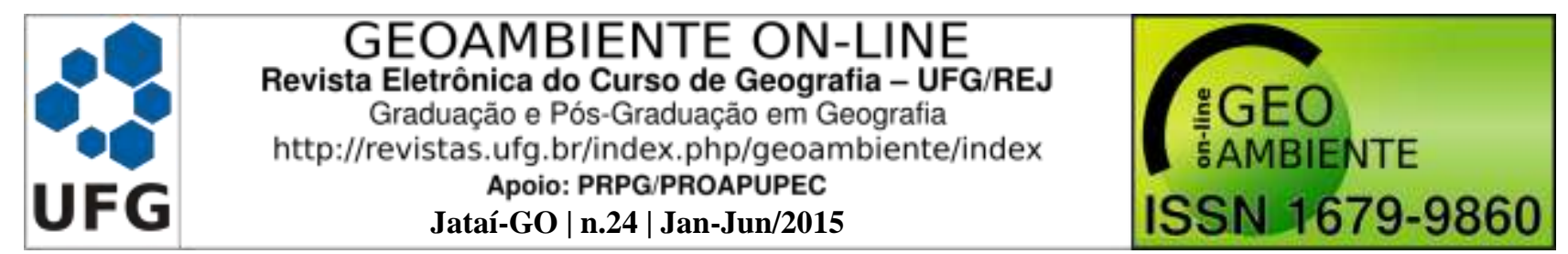

disco de embreagem para automóveis, dentre inúmeros outros produtos vinculados à indústria química (FERREIRA FILHO e LINHARES, 2009).

A Figura 2 apresenta um croqui elaborado pelos primeiros exploradores da região, no intuito de viabilizar o processo de extração do minério. Este croqui foi elaborado entre os dias 28 e 30 de abril de 1962 e podem ser observados a Serra de Cana Brava, o rio Tocantins, alguns pontos que possivelmente são propriedades, um tracejado indicando o trajeto percorrido a cavalo e a sudeste da Serra de Cana Brava, indicado pela seta vermelha, um tracejado retilíneo indicando a área de ocorrência do minério e as futuras instalações da mineradora.

Figura 2: Croqui das imediações da jazida de amianto. Tracejado retilíneo indicado por seta vermelha, indica local de ocorrência do amianto e futuras instalações da usina.

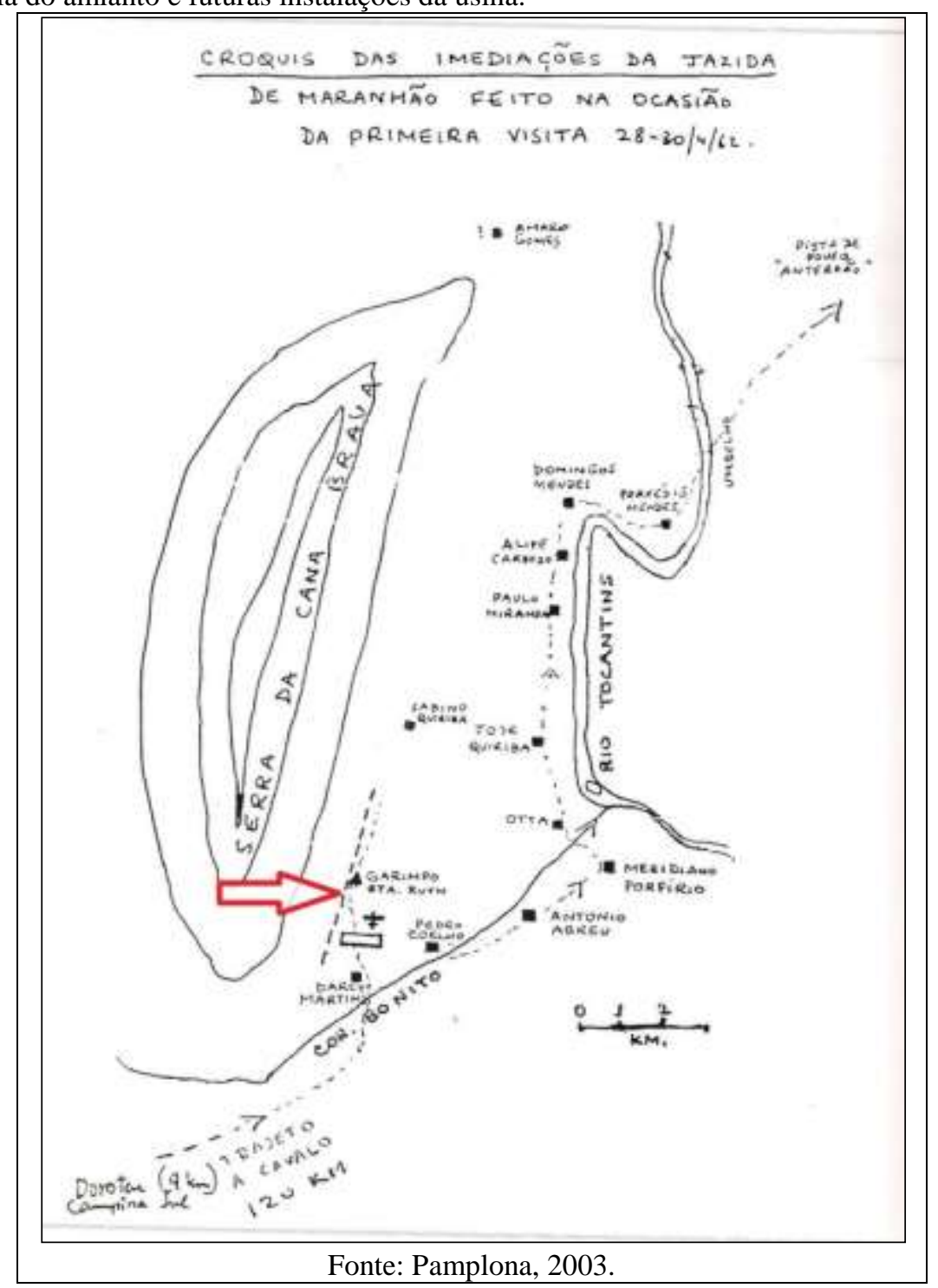

O processo de extração perpassa basicamente pelas etapas de planejamento de lavra, decapeamento, perfuração e desmonte, beneficiamento e deposição dos rejeitos. Esses 


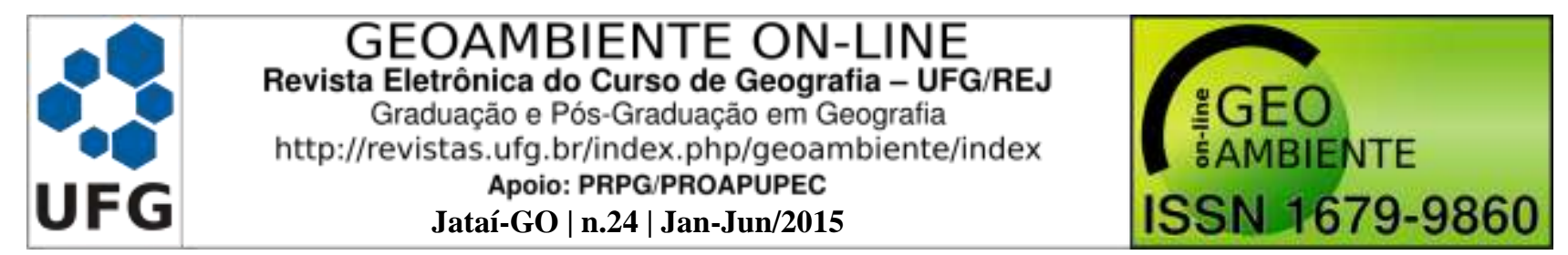

procedimentos são descritos detalhadamente em SAMA (2012) e uma síntese é apresentada a seguir.

\begin{abstract}
A etapa inicial do processo de extração da fibra é denominada de decapeamento, onde é retirada a cobertura vegetal, o solo e a rocha, para assim expor o minério. O solo e a rocha são removidos por escavadeiras e transportados em caminhões basculantes e depositados em sua maioria nas bancas de rejeito. A etapa seguinte é caracterizada como perfuração e desmonte, onde ocorre a fragmentação do maciço rochoso através da perfuração e instalação de explosivos que vão provocar o desmonte da estrutura em blocos que são transportados para beneficiamento ou para as bancas de estéril (SAMA, 2012).
\end{abstract}

Todo o complexo de extração do amianto é composto pela usina, duas cavas e duas bancas. Nas cavas ocorrem os processos de decepamento, desmonte e retirada das fibras e estéril, sendo identificadas como cavas A e B. Segundo informações divulgadas no site mineradora SAMA, as dimensões destas cavas na atualidade são as seguintes: cava A - 156 metros de profundidade e diâmetros de 1.450 metros no sentido norte-sul e $600 \mathrm{~m}$ no sentido leste-oeste; cava B - 169 metros de profundidade e diâmetros de 1.110 metros no sentido norte-sul e 850 metros no sentido leste-oeste (SAMA, 2012).

Ainda segundo dados divulgados pela SAMA, o processo de mineração remove anualmente em torno de 16 milhões de toneladas de material rochoso, sendo que deste total se extrai aproximadamente 302 mil toneladas da fibra de amianto (SAMA, 2012). Todo o rejeito/estéril que sobra desse processo é depositado em duas bancas, também denominadas de banca A e banca B, e possuem as seguintes dimensões: a banca A - $1.041 \mathrm{~m}^{2}$ de área e altura em torno de 80 metros; banca $\mathrm{B}-1.839 \mathrm{~m}^{2}$ de área e altura em torno de 100 metros. Na Figura 3 podem ser observadas as cavas e bancas delimitadas sobre um modelo digital de terreno.

A disposição do estéril e do rejeito retirados da mina é feita de maneira que certifique a firmeza das bancas. Assim, a altura, a inclinação e o espaçamento entre cada talude (berMas) possuem metragens predeterminadas para garantir que o escoamento superficial e a gravidade não comprometam a estabilidade da estrutura. Segundo Pamplona (2003). Este processo ocorre desde 1986 sob orientação técnica do Instituto de Pesquisas Tecnológicas IPT do estado de São Paulo, que estabeleceram as seguintes medidas: bancos $10 \mathrm{~m}$ de altura; taludes inclinação inferior a 1:1; bermas, inclinadas ligeiramente para dentro da banca e com largura de 4 a 6m; cobertura de solo, $30 \mathrm{~cm}$ no mínimo; e canaletas de drenagem feitas com cascata de concreto, solo-cimento e rocha estéril.

Após a deposição de solos (regolito) corrigidos e fertilizados nos taludes, inicia-se o processo de revegetação, atividade esta que também ocorre sob orientações do IPT. A 


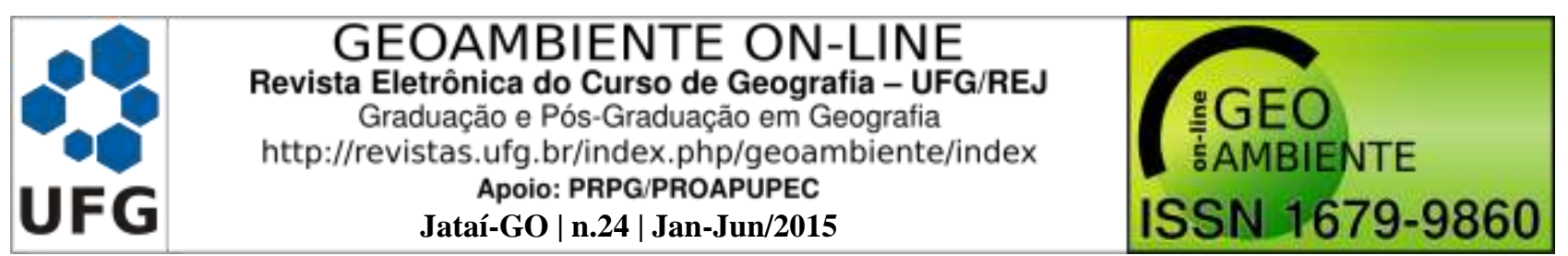

revegetação tem a função de dar estabilidade aos taludes escalonados e evitar a erosão. Para isso, são utilizadas gramíneas e leguminosas e posteriormente são introduzidas árvores e arbustos (PAMPLONA, 2003). Essas técnicas se tornaram necessárias não só em vista das exigências legais, mas também do considerável avanço do processo produtivo, resultado da implementação de tecnologias.

Figura 3: Cavas e bancas em relevo sombreado sobreposta com curvas de nível com equidistância de $10 \mathrm{~m}$.

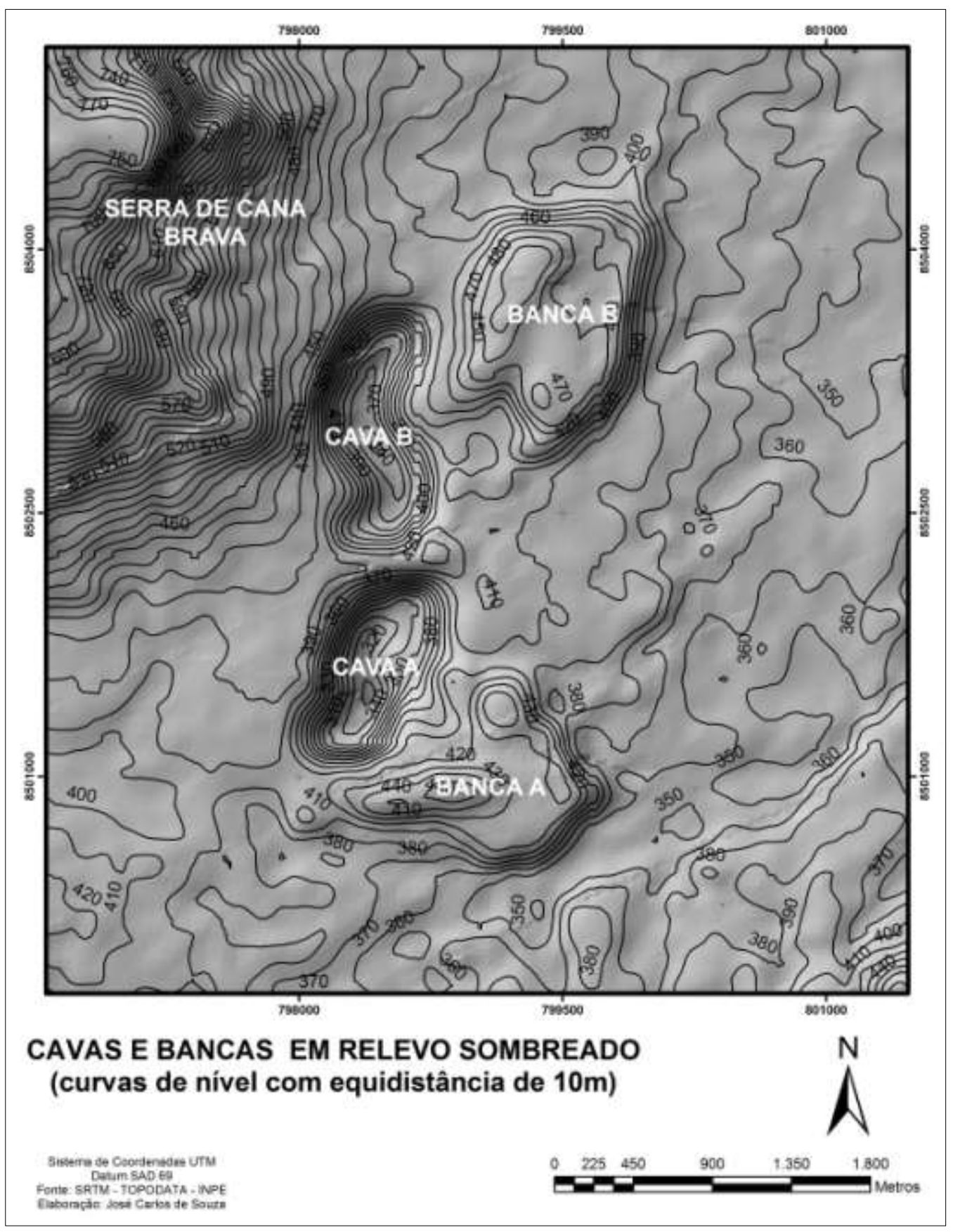

Fonte: SRTM-Topodata-INPE. 


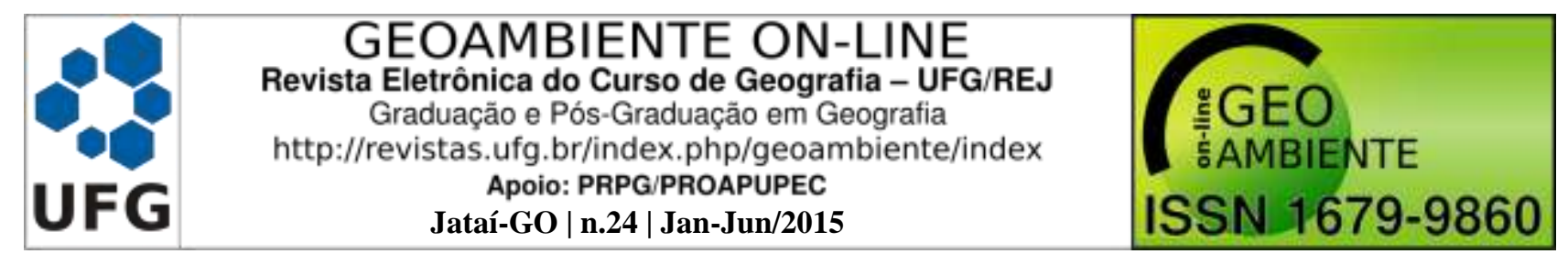

O gráfico da Figura 4 apresenta a evolução no processo de produção do minério no período de 1967 a 2010, onde se percebe um expressivo crescimento que, segundo Pamplona (2003), é resultado dos investimentos em tecnologia. Em 1967 a produção foi de 992 t, em 2010 foram extraídas 306.350 toneladas. Deste total de minério extraído em 2010, 53,40\% da produção foi comercializado no mercado nacional e 46,6\% foi exportado, sendo que os principais mercados foram: Índia, Indonésia, Tailândia, Colômbia, México, Malásia, Emirados Árabes Unidos, China, África do Sul e Equador (FERREIRA FILHO e LINHARES, 2009; DEPARTAMENTO NACIONAL DE PRODUÇÃO MINERAL, 2010).

Figura 4: Evolução da produção de Amianto Crisotila. Pamplona, 2003;

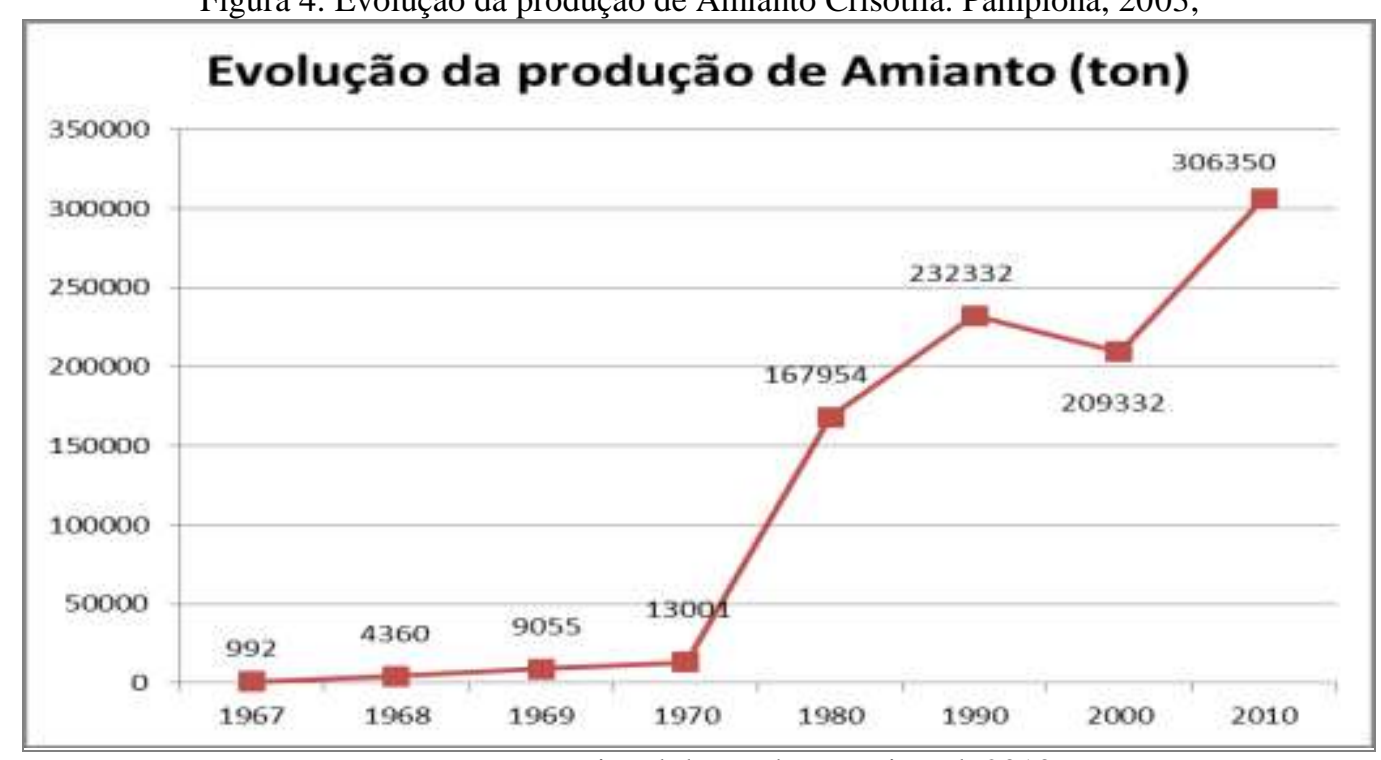

Departamento Nacional de Produção Mineral, 2010.

Com o crescimento significativo da produção, resultado da implementação de tecnologias, as alterações topográficas foram crescentes e cumulativas. As Figuras 5 e 6 ilustram muito bem essa transformação provocada pela introdução de técnicas modernas no processo de extração do amianto. A Figura 5, registro fotográfico de 1966, ilustra o quanto o processo de mineração era rudimentar, sem uso de tecnologias e com trabalho totalmente manual. Neste momento já se notavam as primeiras alterações na morfologia. Na Figura 6, registro atual da mina, percebem-se significativas alterações na paisagem, onde formas exuberantes já são percebidas, como também a utilização de maquinários de alta tecnologia, e grande potencial de intervenção no meio físico como máquinas perfuratrizes, pás-mecânicas e caminhões, processo totalmente tecnificado e com alto poder de intervenção.

De 1969 a 2002 o processo de extração de amianto retirou das duas cavas 247.337.191 de toneladas de minério, estéril e solo (PAMPLONA, 2003) deste total, 82.692.925 


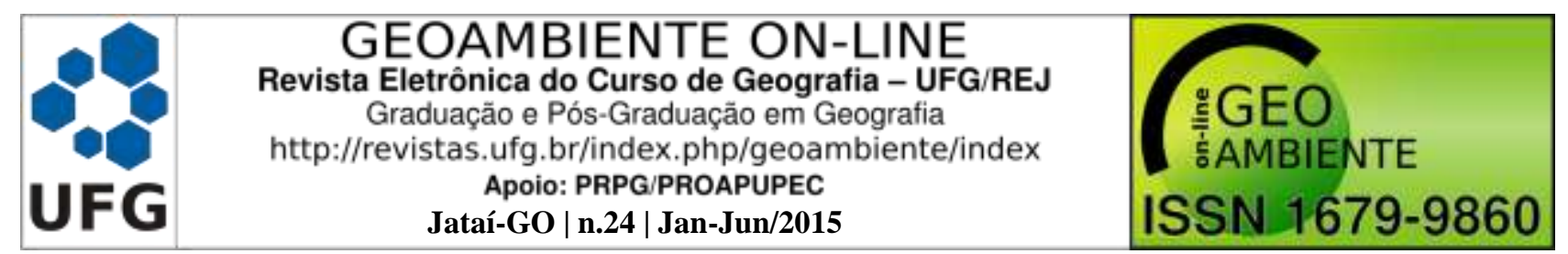

compreende a fibra do amianto. Conclui-se então que 164.644.266 de toneladas de estéril e solo passaram a compor as imponentes bancas de rejeito.

Figura 5: Processo de extração manual do amianto em 1966.

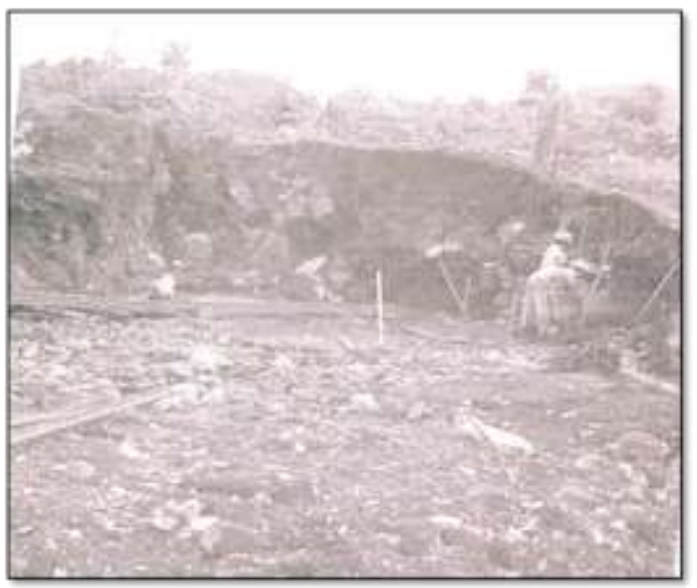

Fonte: Pamplona (2003).
Figura 6: Máquinas perfuratrizes em processo de perfuração e desmonte.

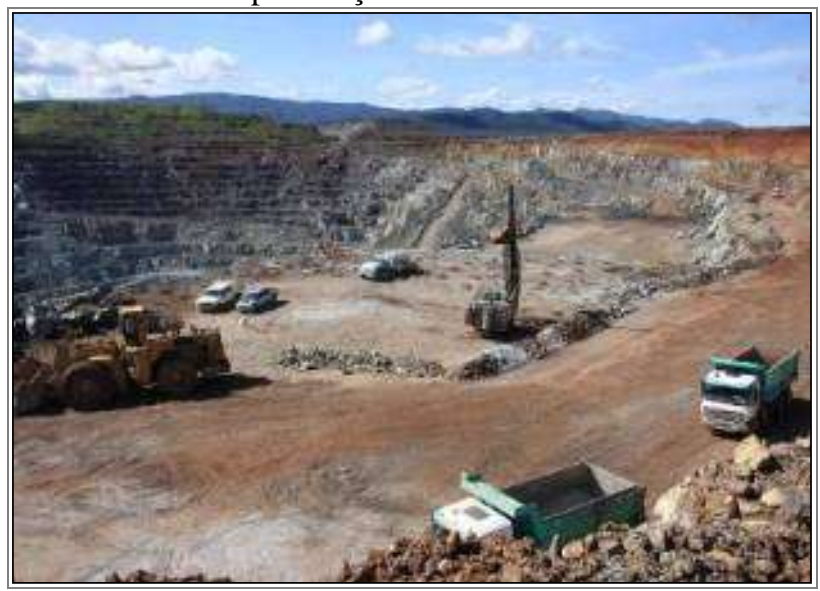

Fonte: www.sama.com.br(2012).

Fazendo uma média simples dos dados apresentados para este período, para se extrair uma tonelada de minério, produziu-se em torno de duas toneladas de rejeito. Já no período de 2003 a 2007, segundo dados apresentados por Ferreira Filho e Linhares (2009), foram extraídos 1.200.739 toneladas do minério, tendo que para isso remover 18.587.046 toneladas de rocha.

Já somam mais de quarenta anos de atividade mineradora e este processo de escavação e deposição formou modelados que surpreendem por suas dimensões. Na Figura 7 podem-se perceber as alterações topográficas provocadas. No segmento A-B as duas cavas de onde, no período de 1969 a 2007, foram retirados mais de 250 milhões de toneladas de rocha e no segmento C-D as duas bancas onde foram depositados os rejeitos deste processo.

As cavas, por estarem entre as bancas e a Serra de Cana Brava, somente são percebidas por imagem de satélite ou foto aérea. No entanto, as bancas, com suas formas simétricas, compostas por uma sobreposição de taludes, podem ser facilmente visualizadas por quem está na área urbana de Minaçu ou nas proximidades. A Figura 8 demonstra as alterações provocadas pela deposição dos rejeitos, num período superior a quarenta e cindo anos, o registro foi feito em 2011, se percebe o processo de antropização da paisagem. Entre a área urbana e a Serra de Cana Brava, uma das bancas (banca B) que compõe o complexo de extração do amianto. 


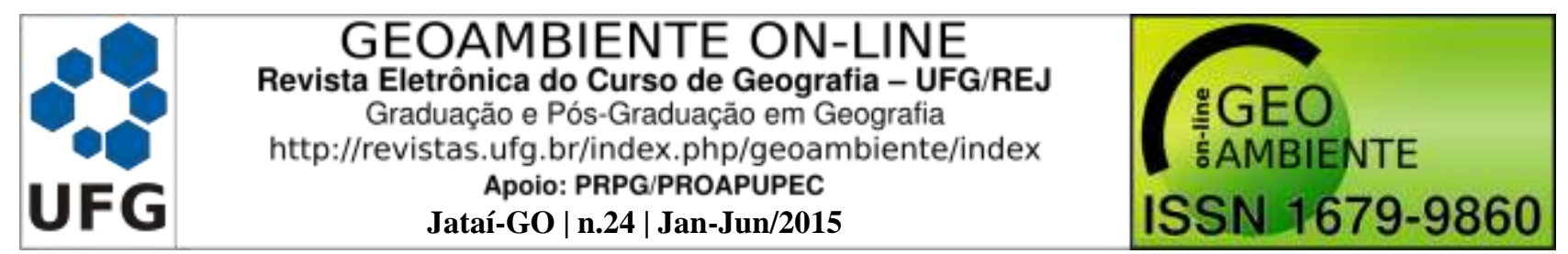

Figura7: Perfis topográficos da área de mineração, segmentos traçados sobre imagem CBERS 2B HRC.
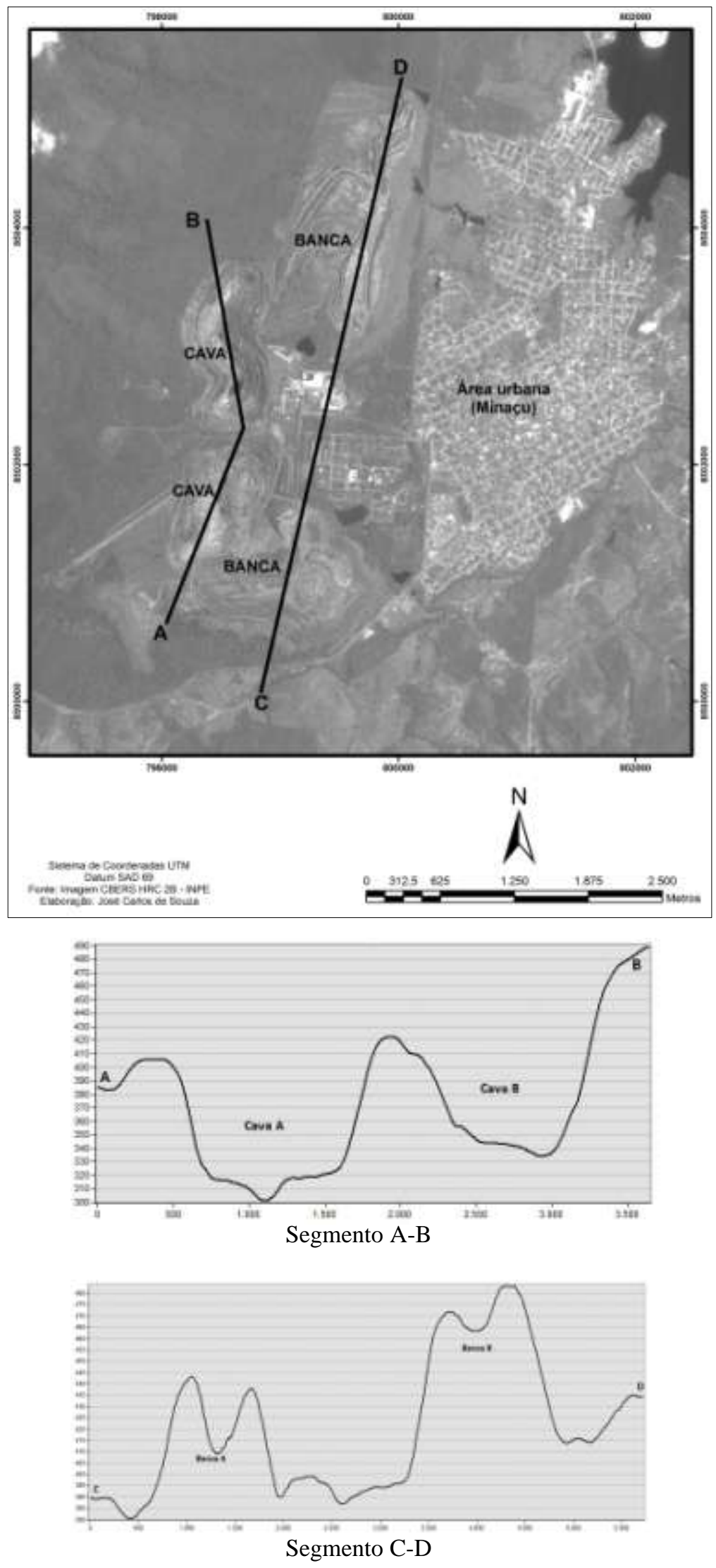


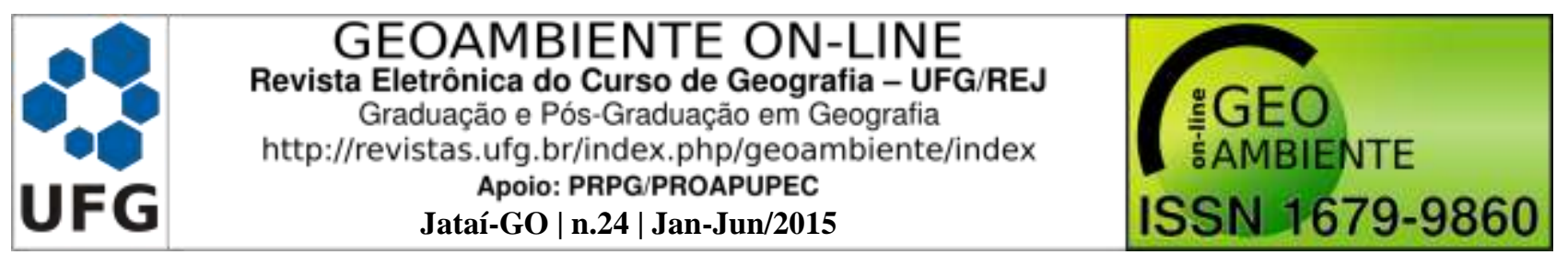

Figura 8: Em primeiro plano, área urbana de Minaçu. Em segundo, bancas de rejeito e logo atrás a Serra de Cana Brava, 2011.

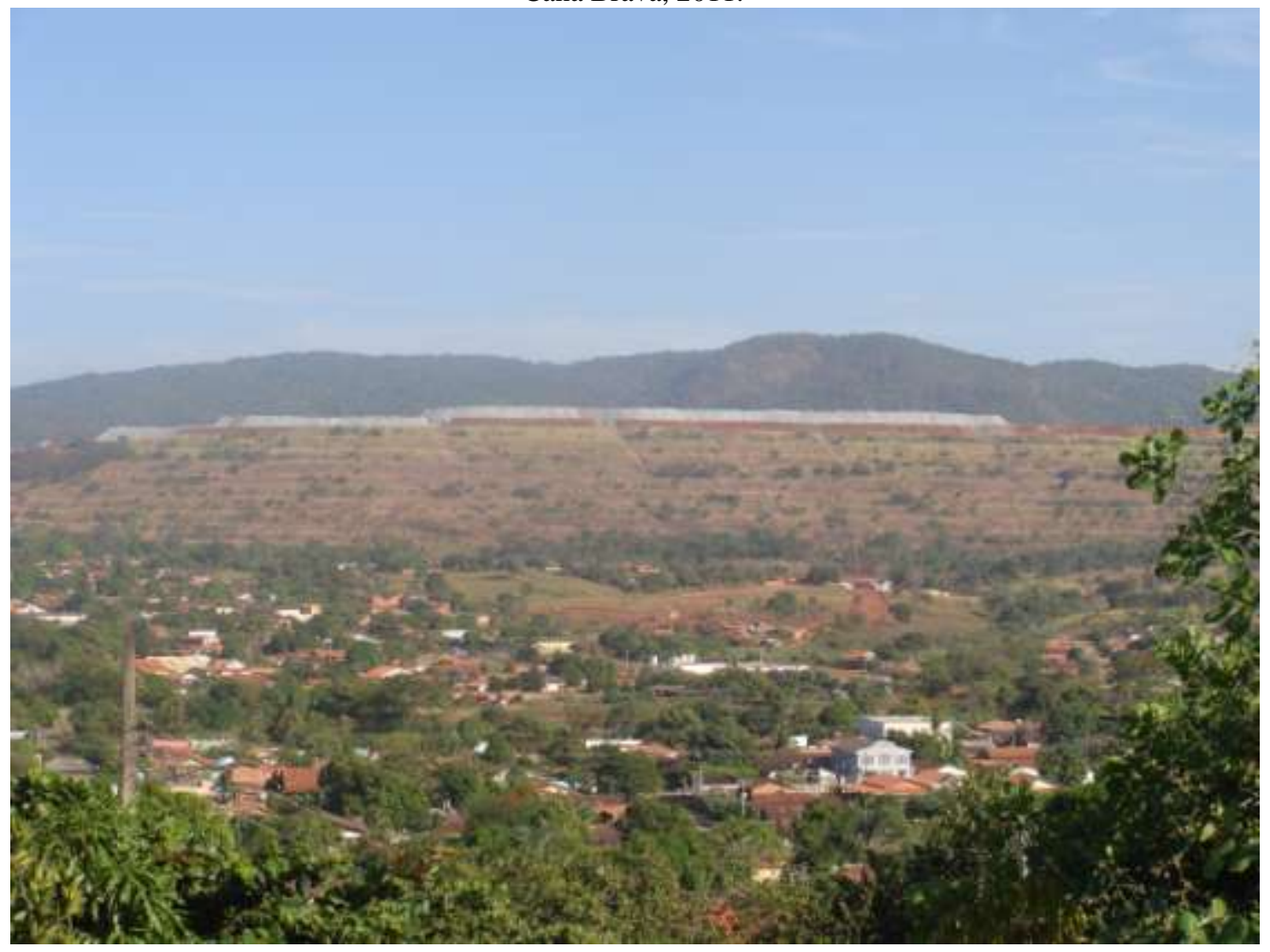

A mineração do amianto se confunde com a história da cidade, pois a cidade surge para abrigar os operários que vieram servir de mão de obra no processo de produção. Em função disso, ao passo que as formas antropogênicas foram evoluindo, a cidade acompanhou este processo, se expandindo à sua volta, acostumando assim com a paisagem artificial dos taludes que têm sua aparência simétrica e artificial amenizadas pelas gramíneas e arbustos que as recobrem. As bancas e as cavas fazem parte da paisagem da cidade e todo este cenário de transformação provocado pelo homem, neste meio físico, compõe objeto de estudo da Antropogeomorfologia.

\section{Considerações finais}

A mineração figura entre as atividades que mais causam alterações na superfície, especialmente as que se processam a céu aberto, porém, poucos estudos, sob a ótica da geomorfologia, têm explorado as transformações provocadas no meio físico por esta atividade. Os estudos e análises muita das vezes tem explorado as consequências do uso e da apropriação de áreas urbanas e rurais sem planejamento, como erosões e movimentos de massa, compreendidos como processos antropogeomorfológicos indiretos. 


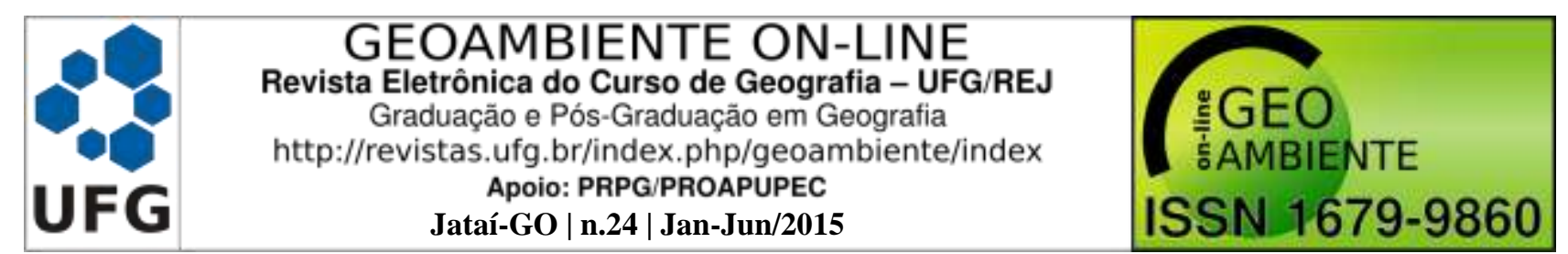

Um processo de extração de minério, realizado dentro dos padrões estabelecidos pela legislação, se enquadra no campo da antropogeomorfologia direta, pois todas as alterações são pensadas e os procedimentos seguem padrões pré-estabelecidos. $\mathrm{O}$ aparato tecnológico também precisa ser considerado neste processo, pois contribui no planejamento da lavra, no processo de extração e no beneficiamento minério, possibilitando o aumento da produção e consequentemente da alteração no meio físico.

O processo de extração do amianto crisotila em Minaçu, que acontece a mais de quarenta anos, vem remodelando a superfície, numa demonstração de que o homem é um agente geomorfológico e suas ações são potencializadas pelo uso de tecnologias modernas. A constante e cumulativa remoção de rochas e solos criam e recriam formas de relevo, demostrando a capacidade humana em transformar os ambientes naturais no intuito de produzir riquezas. Neste sentido é cada vez mais evidente a inserção do homem no patamar dos processos exógenos de modelação relevo e isto representa a legitimação da Antropogeomorfologia enquanto especialidade da Geomorfologia.

\section{Referências}

BROWN, E. H. O homem modela a Terra. In: Boletim Geográfico do Instituto Brasileiro de Geografia e Estatística, Rio de Janeiro, n. 222, p. 03-18, mai/jun, 1971.

CASSETI. V. Elementos de geomorfologia. Goiânia, GO: ed. UFG, 2001.

CHRISTOFOLETTI, A. Aplicabilidade do Conhecimento Geomorfológico nos Projetos de Planejamento. In: GUERRA, A. J. T.; CUNHA, S. B. da. Geomorfologia: Uma atualização de bases de conceitos. $4^{\mathrm{a}}$ ed. Rio de Janeiro: Bertrand Brasil, 2001.

BRASIL. DEPARTAMENTO NACIONAL DE PRODUÇÃO MINERAL (2010). Anuário Mineral Brasileiro. Brasília, 804 p.

FELDS, E. Geomorfologia Antropogenética. BRASIL. IBGE-Instituto Brasileiro de Geografia e Estatística, Boletim Geográfico do., Rio de Janeiro, n. 144, p. 352-357. 1957.

FERREIRA FILHO, O. B. e LINHARES, W. B. (2009). Crisotila. In: BRASIL, Departamento Nacional de Produção Mineral. Economia Mineral do Brasil, Coord. Antônio Ferreira da Silva Rodrigues. Brasília-DF: DNPM, pp. 655-679. 2009.

FLORENZANO, T. G. Introdução à Geomorfologia. In: FLORENZANO, T. G. (org.). Geomorfologia: conceitos e tecnologias atuais. São Paulo: Oficina de Textos, pp. 11-30. 2008. 


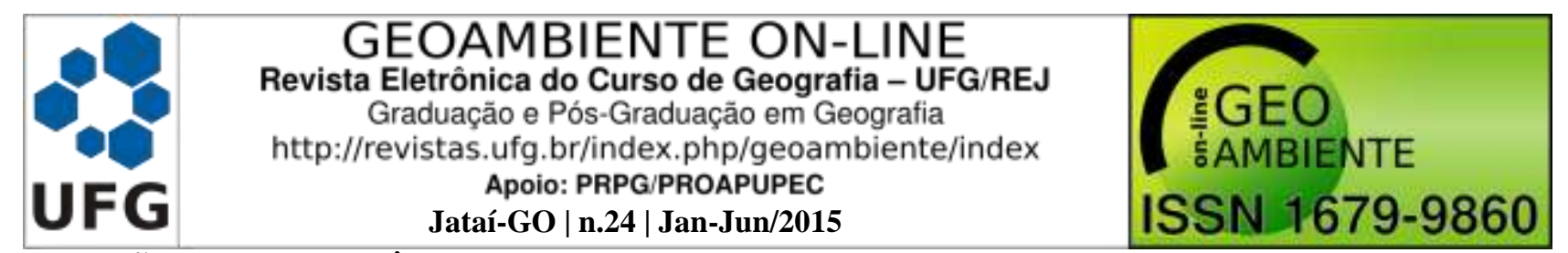

GIRÃO, O. e CORRÊA, A. C. de B. A contribuição da geomorfologia para o planejamento da ocupação de novas áreas. Revista de Geografia. Recife: UFPE DCG/NAPA, v. 21, n0 2, jul/dez. 2004.

GOIÁS. Secretaria da Indústria e Comércio. Superintendência de Geologia e Mineração. Geomorfologia do Estado de Goiás e Distrito Federal. Por Edgardo M. Latrubesse, Thiago Morato de Carvalho. Goiânia, 2006.

GUERRA, A. J. T. e MARÇAL, M. dos S. Geomorfologia Ambiental. Rio de Janeiro: Bertrand Brasil, 2006.

JORGE, M. do C. O. Geomorfologia Urbana: conceitos, metodologias e teorias. In: GUERRA, A. J. T. Geomorfologia Urbana. Rio de Janeiro: Bertrand Brasil, 2011.

MARQUES, J. S. (2011). Ciência Geomorfológica. In: GUERRA, A. J. T. e CUNHA, S. B. da. Geomorfologia: Uma atualização de bases de conceitos. $4^{\mathrm{a}}$ ed. Rio de Janeiro: Bertrand Brasil, 2001.

MOREIRA, M. L. O.; MORETON, L. C.; ARAÚJO, V. A.; LACERDA FILHO, J. V.; COSTA, H. F. Geologia do Estado de Goiás e do Distrito Federal. Ministério de Minas e Energia. Governo do Estado de Goiás. CPRM-Companhia de Pesquisa de Recursos Minerais - Serviço Geológico do Brasil, FUNMINERAL, 2008.

PAMPLONA, R. I. O amianto crisotila e a Sama: 40 anos de historia Minaçu-Goiás: da descoberta a tecnologia limpa. Minaçu, GO: SAMA, 2003.

PELOGGIA, A. O homem e o ambiente geológico: geologia, sociedade e ocupação urbana de São Paulo. São Paulo: Xamã, 1998.

PENTEADO, M. M. Fundamentos de Geomorfologia. BRASIL. IBGE. $3^{\text {a }}$ ed. Rio de Janeiro: 1983.

SANTOS, M. Metamorfoses do Espaço Habitado: Fundamentos Teórico e metodológico da Geografia. $4^{\text {a }}$ Ed. São Paulo: Hucitec, 1996.

RODRIGUES, C. Morfologia original e morfologia antropogênica na definição de unidades espaciais de planejamento urbano: exemplo na metrópole paulista. In: Revista do Departamento de Geografia da Universidade de São Paulo (USP), v. 17. P. 101-111. 2005.

SANTOS FILHO, R. D. (2011) Antropogeomorfologia Urbana. In: Guerra, A. J. T. Geomorfologia Urbana. Rio de Janeiro, RJ: Ed. Bertrand Brasil, 2011.

SAMA. Minerações Associadas. Processo de Produção. Disponível em: <www.sama.com.br> acesso em: Agosto de 2012. 